\title{
Prior Similar Acts in Prosecutions for Rape and Child Sex Abuse*
}

\author{
Sara Sun Beale
}

$\mathrm{T}$

wo events that occurred in the United States in the early 1990 s

focused public attention on the rules governing the admissibility of prior similar acts in prosecutions for rape and child sex abuse.

The first event was a Bush administration proposal to amend the Federal Rules of Evidence to add new rules authorizing the admission of acts of a similar character in a prosecution for either sexual assault or child sex abuse. ${ }^{1}$ Although relatively few rape and child sex abuse cases are prosecuted in the federal courts, this proposal is significant because most states now base their own rules of evidence on the Federal Rules. Although the $102 \mathrm{~d}$ Congress did not ultimately enact these changes, virtually identical proposals have been introduced in the $103 \mathrm{~d}$ Congress. ${ }^{2}$

The second event was the highly publicized acquaintance rape

This article was originally presented at the Society for the Reform of Criminal Law Conference on "Reform of Evidence Law," Vancouver, British Columbia, Canada, August 3-7, 1992.

** Professor of Law, Duke University, Durham, North Carolina, U.S.A.; B.A., University of Michigan 1971; J.D., University of Michigan 1974.

1 Comprehensive Violent Crime Control Act of 1991, S. 635, 102d Cong., 1st Sess. $\$ 801$ (1991), 137 Cong. Rec. S3192, S3212 (daily ed. Mar. 13, 1991).

2 Sexual Assault Prevention Act of 1993, S. 6, 103d Cong., 1st Sess. $\$ 121$ (1993), 139 Cong. Rec. S269, S272 (daily ed. Jan. 21, 1993); Crime Control Act of 1993 , S. 8, 103d Cong., 1st Sess. $\$ 821$ (1993), 139 Cong. Rec. S288, S312 (daily ed. Jan. 21, 1993). The text of the 1991 bill is set out in the appendix to this article. 
prosecution of William Kennedy Smith, which demonstrated the powerful effect that the proposed amendment might have. The complainant in the Smith case testified that she met Smith in a bar and agreed to accompany him to the place where he was staying. She alleged that when they arrived at the Kennedy estate, Smith suddenly disrobed, grabbed her when she tried to run away, and raped her on the beach. Smith conceded that intercourse had occurred but contended that it had been consensual. The jury acquitted Smith. The jurors were not permitted to hear the testimony of three other women who came forward before trial and offered to testify to similar experiences with Smith. ${ }^{3}$ Each of the three women claimed that, after initially acting in a friendly and nonthreatening manner, Smith had suddenly undergone a frightening transformation and assaulted her. ${ }^{4}$ It seems obvious that the result in the Smith prosecution might have been different if the proposed amendment had been in effect and the jury had heard the testimony of the other women.

This article will review the current law in the United States regarding the admissibility of prior similar acts in prosecutions for rape and child sex abuse and evaluate the arguments for and against enacting the proposed amendments.

\section{THE CURRENT LAW}

All U.S. jurisdictions now place significant restrictions on the admission of evidence concerning prior wrongs and crimes committed by the

$3 \quad$ Although no published opinion is available, contemporary press reports state that the judge ruled "their testimony would prejudice the jury against Mr. Smith" and "[t]hat concern outweighed their testimony's value as showing a pattern of behavior" on the defendant's part. Michael Hedges, Other Women Paint Smith as Violent, "Not Too Bright," Wash. Times, Dec. 7, 1991, at A4.

4 One of the women would have testified that Smith raped her, and the other two would have testified that they prevented attempted rapes. Id. One of the women, now a doctor, would have testified that Smith assaulted her in 1988 when she was a medical student, suddenly taking off his clothes after a casual conversation near a pool, acting as if this were normal behavior. Id. This was the closest parallel to the Florida victim's version of the events. 
defendant. There is general agreement that prior acts should not be admitted to prove propensity, and also general agreement on a number of purposes for which prior acts may be admitted, including proof of intent, knowledge, motive, plan, and absence of mistake or accident. ${ }^{5}$ Rule 404(b) of the Federal Rules of Evidence is in force in the federal courts, and it has served as the model for the rules now in effect in more than half of the states. This rule provides:

Other crimes, wrongs, or acts. Evidence of other crimes, wrongs, or acts is not admissible to prove the character of a person in order to show that he acted in conformity therewith. It may, however, be admissible for other purposes, such as proof of motive, opportunity, intent, preparation, plan, knowledge, identity, or absence of mistake or accident.

Although some states have developed special rules, most U.S. jurisdictions purport to apply the general rule described above to rape and child sex prosecutions. A close examination of the cases reveals that the jurisdictions lacking special rules actually fall into two quite different camps. Courts in the first group of states apply the general rule regarding prior acts with the same rigor in rape and child sex prosecutions as in other types of cases, and not infrequently they exclude prior convictions and uncharged conduct of a similar nature. Courts in the other camp, in contrast, also purport to apply the general rule in prosecutions of this nature, but the rule operates quite differently in practice. In these jurisdictions the purposes for which prior acts may be admitted - particularly, intent and plan - are construed so broadly in rape and child sex abuse prosecutions that virtually any similar act is admissible. In effect, courts in these jurisdictions allow proof of prior acts to show propensity if there is the thinnest pretext of some other purpose for the evidence. ${ }^{6}$

5 Jurisdictions do differ, however, on the question whether the generally recognized categories are exhaustive or merely illustrative.

6 The court candidly recognized this point in State v. Kitson, 817 S.W.2d 594, 598 (Mo. Ct. App. 1991) (citations omitted): 
A brief description of a few cases will demonstrate the wide disparity between these approaches. A California decision illustrates how the rigorous application of traditional evidentiary rules can bar evidence of similar acts that would corroborate the complainant's testimony. In People v. Tassell, the state supreme court held that it was error to admit evidence of two earlier uncharged sexual assaults that were introduced to show a common design or plan. ${ }^{7}$ The complainant testified that she met the defendant while she was working as a waitress and agreed to give him a ride home after her shift. She testified that once he was in her van, the defendant grabbed her neck with both hands and pressed his thumbs on her windpipe, pulled her hair, and forcibly had oral and vaginal intercourse. He also told her he would have an alibi if she went to the police and that his name was Mike. Two other women testified to similar experiences. The first witness was also a waitress who met the defendant at work; she, too, claimed that he raped her in her car at the end of her shift. The second witness testified that the defendant picked her up while she was hitchhiking, pressed his thumbs on her windpipe, grabbed her hair, and forced her to have oral and vaginal intercourse. He told this victim that his name was Mike and that his friends would give him an alibi.

The California Supreme Court held that the evidence from these two women should not have been admitted to prove a common plan because the latter is only a "subordinate objective of proof, whose relevance depends upon the presence of some other actual issue, such as identity or innocent intent." ${ }^{8}$ In the case before it, the court concluded there was no issue of identity, since the defendant admitted the intercourse. Nor was there any issue of "equivocal or ambiguous" intent, since neither the prosecution nor the defense claimed that the defendant

Although this concept, labeled the "depraved sexual instinct doctrine" by the Court in Taylor, has been rejected in name, it has been adopted in fact. The evidence of sexual misconduct rejected under this concept is simply admitted under the strained and questionable guise of one of the well established exceptions to the rule prohibiting the use of sexual misconduct to attack character.

679 P.2d 1 (Cal. 1984). Id. at 4 (quoting People v. Covert, 57 Cal. Rptr. 220, 222 (Ct. App. 1967)). 
mistakenly believed that the complainant was consenting.' In light of those circumstances, the court concluded that the common plan rationale was "merely a euphemism for 'disposition," and it should not have been admitted. ${ }^{10}$ In California and other jurisdictions following a similar approach, prior acts are admissible only if the prosecutor can make a convincing showing that the evidence is relevant to some contested issue other than a predisposition to commit rape or acts of child sex abuse. ${ }^{11}$

In contrast, other jurisdictions that purport to follow the same evidentiary rules achieve quite different results. For example, in United States $v$. Peden, a prosecution for rape and sexual abuse of a minor, the court upheld the admission of a prior conviction resulting from the defendant's fondling of another child. ${ }^{12}$ Although the defendant admitted to having had intercourse with the victim, the court concluded that his prior conviction was admissible to show his "intent to take advantage of one incapable of resisting or unable to appreciate the act, as well as his knowledge that young children are easily victimized." ${ }^{13}$ Similarly, in a prosecution for sexual molestation of a fifteen-year-old

$9 \quad I d$. at 7 n.7. Justice Reynoso dissented on this point, arguing that intent was at issue since the defendant claimed that he had intended consensual intercourse, and the prosecution contended that he had intended intercourse by force or threats. Id. at 10 , 11.

$10 \quad$ Id. at 8.

11 Another good example of this approach is State v. Hansen, 608 P.2d 1083 (Mont. 1980). The state supreme court reversed the defendant's conviction for rape because of the introduction of evidence of an earlier uncharged rape. There were numerous similarities between the victims' accounts of the two attacks. Both victims testified that they left a bar with the defendant in the early morning hours, that he drove them up into the mountains, that he grabbed them and twisted their thumbs against their wrists, and that he forced them to have intercourse. The court held that the admission of the uncharged rape was improper because it was not sufficiently contemporaneous and not sufficiently similar to the charged rape, and did not demonstrate a common scheme or plan. The court identified several differences between the two attacks and also suggested that sexual acts originating in barroom pickups are so common that they have little value in establishing a common scheme or plan. Finally, the court concluded that any probative value the evidence might have was outweighed by its prejudicial impact.

13 Id. at 520 
girl, the Iowa Supreme Court upheld the admission of prior conduct with other victims on the ground that this conduct showed the motive of "desire to gratify his lustful desire by grabbing or fondling young girls." ${ }^{14}$ It seems clear that the California Supreme Court would find the evidence in the claims of motive or intent in these cases to be merely a euphemism for propensity or disposition.

A third group of states takes a more forthright position and recognizes that prosecutions for rape and child sex abuse justify a special rule permitting the introduction of prior similar acts by the defendant. As one commentator has stated, in these jurisdictions "intellectual honesty triumphed, and the courts eventually acknowledged that they were recognizing a special exception to the norm prohibiting the use of the defendant's disposition as circumstantial proof of conduct." 15 Originally this exception was limited to prior acts involving the same victim and to conduct deemed abnormal and deviant, such as incest and child molestation, and it did not include heterosexual rape. ${ }^{16}$ Gradually, however, the exception expanded, first to deviant acts involving third parties and then to rape, as well as deviant conduct. ${ }^{17}$

At one time at least twenty states probably followed this third position, recognizing a special rule allowing the admission of prior acts in prosecutions for rape and child sex abuse ${ }^{18}$ but the status of this rule is now uncertain in many jurisdictions. The special exception came under fire in the 1960s, and courts in several states responded by eliminating the rule or imposing limitations. ${ }^{19}$ The introduction of new state evidence codes modeled on the Federal Rules casts further doubt on

\footnotetext{
14 State v. Schlack, 111 N.W.2d 289, 291 (Iowa 1961).

$15 \quad$ Edward J. Imwinkelried, Uncharged Misconduct Evidence $\$ 4: 14$, at 37 (1991).

16 Id. at $36-37$.

17 Id. $\$ \$ 4: 14-4: 15$.

18 See Chris Hutron, Commentary: Prior Bad Acts Evidence in Cases of Sexual Contact with a Child, 34 S.D. L. Rev. 604, 614 n.47 (1989) (approximately twenty states had or have such an exception).

19 Imwinkelried, supra note 15, 4:16-4:17 (New York courts tightened standards without explicit overruling; Arizona imposed procedural limitations). Scholarly critiques of the special rule are collected in id. $\$ 4: 16 \mathrm{nn}$. 6-12.
} 
the survival of a special rule for prior sex crimes, since Rule 404 does not recognize any exemption of this nature. The state courts are divided on the question of whether special state rules should survive the adoption of provisions modeled on Federal Rule 404(b). ${ }^{20}$

\section{THE PROPOSED AMENDMENTS}

The Bush administration's proposal, and the subsequent bills modeled on ${ }^{i t},{ }^{21}$ would add two new provisions to the Federal Rules of Evidence. For convenience, I will discuss these together as the "Bush administration proposal." Proposed Rule $\mathbf{4 1 3}$ would provide:

(a) In a criminal case in which the defendant is accused of an offense of sexual assault, evidence of the defendant's commission of another offense or offenses of sexual assault is admissible, and may be considered for its bearing on any matter to which it is relevant.

Paragraph (d) of this rule defines offenses of sexual assault broadly to include both state and federal offenses involving rape or other forms of sexual assault. Proposed Rule 414 sets out in paragraph (a) a parallel rule of admissibility for evidence of "another offense or offenses of child molestation" offered at a trial for child molestation. Rule 414(d) defines

20 Compare State v. McKay, 787 P.2d 479 (Or. 1990) (holding evidence of prior acts admissible to prove sexual predisposition for this victim), and State v. Edward Charles L., 398 S.E.2d 123 (W. Va. 1990) (holding that prior acts of child sexual assault and abuse with same or different victims may be introduced to show lustful disposition toward particular child or children in general), with Getz v. State, 538 A.2d 726 (Del. 1988) (holding sexual propensity exception inconsistent with Del. Rule Evid. 404(b)); see also Hutton, supra note 18, at 614-15 \& nn.52-54 (noting prevailing view that the sexual propensity exception did not survive the adoption of Rule 404(b), but Arizona and Nebraska have taken a contrary position and lowa has vacillated).

21 See supra notes 1-2. As noted earlier, the various proposals to amend the Federal Rules are virtually identical. The recommended changes are set out in the appendix to this article. 
a child as a person under the age of fourteen, and it defines offenses of child molestation to include state, as well as federal, offenses of child sex abuse. Paragraph (b) of both rules requires that the defendant be given pretrial notice of the prior acts to be offered so that he or she will have a fair opportunity to respond.

The commentary accompanying this proposal explains that evidence admitted under the rule

could be considered as evidence that the defendant has the motivation or disposition to commit sexual assaults, and a lack of effective inhibitions against acting on such impulses, and as evidence bearing on the probability or improbability that the defendant was falsely implicated in the offense of which he is presently accused. ${ }^{22}$

\section{THE RATIONALE FOR THE EXCLUSION OF PRIOR ACTS}

Despite scholarly attacks on the traditional rule barring evidence of prior acts to prove the defendant's character or propensity, and hence actions in conformity therewith, ${ }^{23}$ the general prohibition on character evidence remains firmly rooted in U.S. law. ${ }^{24}$ There are three main reasons given for excluding evidence of prior acts to show propensity and conduct in conformity: irrelevance, prejudice, and procedural efficiency and fairness. In the past ten years, the scholarly debate has included not only the

22137 Cong. Rec. S3239 (daily ed. Mar. 13, 1991).

23 Professor Kuhns has argued persuasively that there is no real distinction between character and noncharacter evidence because both entail assumptions about the accused's tendencies and disposition. Richard B. Kuhns, The Propensity to Misunderstand the Character of Specific Act Evidence, 66 lowa L. Rev. 777 (1981). Others have argued that uncharged crimes can be so highly probative even on a character theory that they should be admitted. H. Richard Uviller, Evidence of Character to Prove Conduct, $130 \mathrm{U}$. Pa. L. Rev. 845, 883, 890 (1982); see also Hutton, supra note 18.

24 See Edward J. Imwinkelried, The Use of Evidence of an Accused's Uncharged Misconduct to Prove Mens Rea, 51 Ohio St. L.J. 575, 576 (1990). 
traditional arguments that shaped the common law but also insights gleaned from modern psychological research.

Some authorities take the position that character evidence based upon prior acts is simply irrelevant to the issue of conduct on another occasion:

The basic reason for the inadmissibility of evidence of other crimes, wrongs, or acts is that such evidence is irrelevant to prove the conduct in question. As Wigmore says, it "has long been accepted in our law $* * *[t]$ hat 'the doing of one act is in itself no evidence that the same or a like act was again done by the same person'***." The reason for this is that our knowledge of the causes of human conduct is too weak to provide any major premise that will support the desired inference. . . . The only explanatory model for human conduct expressly recognized by the law of evidence is the concept of "character." But our confidence in this construct is so weak that its explicit use is only authorized under special circumstances. ${ }^{25}$

The view that character evidence has no predictive value, and hence no relevance, finds some support in modern psychology. The "traits theory" of personality has been discredited by empirical research demonstrating that "behavior is largely shaped by specific situational determinants that do not lend themselves easily to predictions about individual behavior." 26

Other authorities-some of whom concede that character evidence may indeed be probative - focus on the prejudicial impact that such evidence may have. ${ }^{27}$ This view was expressed over forty years ago by the U.S. Supreme Court, which stated that though such evidence is "logically persuasive," it is too powerful with the jury, and likely to persuade them to prejudge the defendant, denying the accused a fair trial

25 22 Charles A. Wright \& Kenneth W. Graham, Federal Practice and Procedure $\$ 5239$, at 436 (1978) (footnotes omitted).

26 Miguel Angel Mendez, California's New Law on Character Evidence, 31 UCLA L. Rev. 1003, 1052 (1984).

27 E.g., 1 Kenneth S. Broun et al., McCormick on Evidence $\$ 190$, at 797-99 (John W. Strong ed., 4th ed. 1992) [hereinafter McCormick]. 
on the charge. ${ }^{28}$ In recent years, evidence scholars have offered psychological data to buttress the courts' commonsense view of the potential for prejudice from the introduction of prior bad acts. Particular attention has been given to what psychologists call the "halo effect": the propensity to oversimplify and judge others on the basis of some outstanding good or bad quality. ${ }^{29}$ In addition, psychologists have identified other factors that tend to prejudice jurors against a defendant if prior bad acts are introduced. First, there is evidence that people tend to give greater weight to negative or derogatory information about others than they do to positive information of equal intensity. ${ }^{30}$ People also overestimate the predictive value of data by making predictions based upon very small samples that statisticians would consider inadequate. ${ }^{31}$ Unfortunately, the inaccurate perceptions that result are difficult to shake, for people tend to interpret all subsequent data so as to maintain their initial belief. ${ }^{32}$

Finally, the introduction of past acts to show character and ultimately action in conformity raises procedural concerns. The introduction of evidence about events other than those charged in the indictment may be burdensome and time-consuming, bringing in collateral issues that distract the jury from the main issue. ${ }^{33}$ In cases in which the defendant wishes to challenge the occurrence of the other acts, the potential for delay and confusion is significant.

\section{THE ARGUMENTS FOR AND AGAINST AN EXCEPTION}

The principal reason for following a special rule admitting prior acts of rape or child sex abuse is the structural difficulty of proving sexual

Michelson v. United States, 335 U.S. $469,475-76$ (1948).
$29 \quad$ Mendez, supra note 26 , at $1047-48$.
$30 \quad$ Id. at $1045-46$.
$31 \quad$ Id. at 1048.
$32 \quad$ Id. at 1054.
$33 \quad$ See, e.g., McCormick, supra note 27 , at $797-98$.


offenses under the current evidentiary rules. The offenses virtually always occur in private and there is little, if any, corroborative physical evidence in most cases. ${ }^{34}$ Hence the cases tend to come down to the complainant's word versus the word of the defendant, with the prosecution required to prove the offense beyond a reasonable doubt. This structural problem is difficult to overcome in the case of the rape of an adult, and it is heightened in a prosecution for child sex abuse, where the victim may be very young. ${ }^{35}$ Under these circumstances, the verdict often turns on the availability of evidence that can be used to resolve the swearing contest between complainant and defendant. While it is true that there are other offenses, such as theft, that often occur in a clandestine fashion, treating sex offenses differently from other clandestine offenses may be justified. The injury resulting from sex offenses is more serious than that associated with most other offenses, and there is a correspondingly greater need to prosecute offenders successfully. Few people would dispute that the sexual abuse of a child works a more profound and lasting harm than a theft and that society has a greater responsibility to identify and punish sex offenders than thieves.

34 This statement is generally accurate in most acquaintance rape cases and many child sex abuse cases. Physical evidence typically plays a more significant role in stranger rape cases, where there may be evidence of physical trauma consistent with the use of force, as well as blood or semen, which may help establish the rapist's identity.

35 The court in State v. Edward Charles L., 398 S.E.2d 123, 132-33 (W. Va. 1990) (citation omitted), described some of the special problems in proving child sex abuse:

[T] hese cases generally pit the child's credibility against an adult's credibility and often times an adult family member's credibility. Since sexual abuse committed against children is such an aberrant behavior, most people find it easier to dismiss the child's testimony as being coached or made up or conclude that any touching of a child's private parts by an adult must have been by accident. In addition, children often have greater difficulty than adults in establishing precise dates of incidents of sexual abuse, not only because small children don't possess the same grasp of time as adults, but [also] because they obviously may not report acts of sexual abuse promptly, either because they are abused by a primary care-taker and authority figure and are therefore unaware such conduct is wrong, or because of threats of physical harm by one in almost total control of their life. 
Recognition of this structural difficulty sets the stage for a reconsideration of the objections to prior act testimony in this distinctive context. As noted above, three concerns underlie the rule excluding such evidence: irrelevance, prejudice, and procedure. It is these concerns that must be reassessed in the context of the Bush administration proposal.

The procedural objections are most easily met. The Bush administration proposal itself disposes of one procedural concern by providing the defendant with pretrial notice and an opportunity to respond to any prior acts that will be introduced. The traditional rule of exclusion is also based upon the concern that introduction of evidence of prior acts would unduly prolong trials and tend to distract the jury from the main issue. Certainly the introduction of evidence of prior acts would somewhat prolong the trials in question. ${ }^{36}$ Proponents of admission argue, however, that given the importance of successful prosecutions of sex crimes, longer trials are acceptable. Moreover, proponents also argue that evidence of other similar acts would not distract jurors but rather would assist them in resolving correctly the key issue in dispute: whether the complainant or the defendant is telling the truth. The determination of whether such evidence imposes an undue burden on the court or distracts the jury thus ultimately comes down to the question of whether evidence of this type is relevant and highly probative on the disputed issues, or is - as the general rule barring such evidence assumes - of little or no probative value and highly prejudicial.

To frame the debate in terms of the William Kennedy Smith prosecution, if the evidence of the other assaults was indeed highly probative of the question whether the complainant or the defendant was telling the truth, it would not have been a distraction from the main issue, and it would have been appropriate to extend the trial to admit this evidence. On the other hand, if the evidence was of little or no probative value, though it would have been given great weight by the jury, the trial should not have been extended to admit this evidence.

Two different arguments can be made regarding the relevance of prior sex crimes. The first, which was typically used by the courts that

36 It is not clear how burdensome this would be in a typical case. Relatively few witnesses may be needed or indeed be available to prove prior acts that also occurred in private, where the only witness may be the alleged victim. 
developed the common law exception admitting such evidence, is that such conduct is relevant to show an abnormal sexual predisposition strongly linked to repetitive conduct. ${ }^{37}$ The Bush administration proposal relies in part on this argument. The accompanying commentary argues that prior acts are relevant to show the defendant's "motivation or disposition to commit such offenses" in sexual assault cases. ${ }^{38}$ This argument is said to be especially strong in child sex abuse cases, since "[e]vidence of other acts of molestation indicates that the defendant has a type of desire or impulse - a sexual or sexual-sado interest in young children-that simply does not exist in normal people." ${ }^{39}$

Though it is popularly believed that sexual offenders are far more likely than other offenders to repeat their offenses, the reality is more complex. The common law sexual propensity exception has been attacked on the ground that the statistics on criminal history actually show that sex offenders have a lower recidivism rate than other categories of offender, ${ }^{40}$ though this argument has been attacked in turn by scholars who point out that the data in question omit undetected recidivism. ${ }^{41}$ Since sexual offenses are often not reported, data based only on reported crimes may be quite misleading. Although methodological problems limit the conclusions that can be drawn at present, studies including selfreporting show much higher rates of repeated conduct than the data on reported crimes indicate, ${ }^{42}$ and there is evidence that repetition of some forms of conduct is especially likely. ${ }^{43}$

37 Imwinkelried, supra note $15, \$ 4: 14-4: 15$.

38137 Cong. Rec. S3240 (daily ed. Mar. 13, 1991).

$39 \quad$ Id.

40 Imwinkelried, supra note $15, \$ 4: 16$.

41 Hutton, supra note 18 , at $622 \& \mathrm{n} .82$.

42 David Finkelhor, Abusers, in A Sourcebook on Child Sexual Abuse 119, 336

(1986). See generally Lita Furby et al., Sex Offender Recidivism, 105 Psychol. Bull. 3 (1989).

43 Finkelhor, supra note 42, at 134 (all studies surveyed found abusers of boys among the most likely to repeat; three studies found them more than twice as likely to repeat as offenders against girls); Furby et al., supra note 42, at 27 (two studies found 
Indeed, the psychiatric profession recognizes pedophilia as a disorder characterized by "recurrent, intense sexual urges and sexually arousing fantasies, of at least six months' duration, involving sexual activity with a prepubescent child." ${ }^{\text {44 }}$ Given this definition of a trait or predisposition that is defined by an intense urge or propensity for certain conduct, it is difficult to argue that prior acts that might in turn demonstrate the trait of pedophilia are not relevant to the question whether a given individual has sexually abused a child. Moreover, within the general category of pedophilia it is possible to identify types of individuals who are more likely than others to repeat their conduct, and also to identify circumstances under which certain types of pedophiles are especially likely to commit additional offenses. ${ }^{45}$ One need not accept the discredited character trait theory of personality to agree that a few traits or conditions, such as pedophilia, do have predictive value.

On the other hand, neither the recognition of pedophilia as a psychiatric condition characterized by intense, recurrent, and long-term sexual urges nor the data suggesting that recurrent conduct is characteristic of some forms of pedophilia justifies the wholesale treatment of sexual offenses in the Bush administration proposal. "Isolated sexual acts with children" - which would be admissible under the proposed changes - "do not necessarily warrant a diagnosis of Pedophilia." 46 Moreover, as noted earlier, different forms of pedophilia seem to show different rates of recidivism, and it is questionable whether rape has the same distinctive etiology providing predictive value. ${ }^{47}$ Thus, while arguments based upon

lower rate of recidivism for pedophiles than for aggressive/assaultive offenders, that is, rapists); Hutton, supra note 18, at 620-23 (distinguishing fixated and regressed child molesters).

44 Diagnostic and Statistical Manual of Mental Disorders (DSM III-R) 284 (3d rev. ed. 1987) (emphasis added) [hereinafter DSM III-R].

45 Finkelhor, supra note 42, at 134-36; Hutton, supra note 18, at 619-23.

46 DSM III-R, supra note 44 , at 285.

47 For example, some data suggest that a large percentage of college-age men would engage in forcible sexual intercourse if they thought they would not be punished for that behavior. See, e.g., Neil Malamuth et al., Testing Hypotheses Regarding Rape, 14 J. Res. Personality 121, 130, 134 (1980) (51 percent of male college students in sample 
the likelihood of repetition, and hence the greater probative value of prior acts, might justify a more narrowly tailored exception for some forms of child sex abuse, ${ }^{48}$ they do not provide a convincing basis for the broader rules proposed by the Bush administration.

The proposed changes also provide a second, more broadly applicable rationale for admitting prior acts of rape and child abuse. The proposal relies on what Wigmore called the "doctrine of chances," treating prior similar acts as "evidence of the improbability that the defendant has been falsely or mistakenly accused of the crime." 49 As the commentary explains:

It is inherently improbable that a person whose prior acts show that he is in fact a rapist or child molester would have the bad luck to be later hit with a false accusation of committing the same type of crime, or that a person would fortuitously be subject to multiple false accusations by a number of different victims. ${ }^{50}$

This reasoning applies not only when identity is at issue but also when the defendant admits that he had intercourse with the victim but claims that she consented. ${ }^{51}$ While in individual cases the force of this probabilistic argument may be decreased by showing that the different accusations were not independent or that there is a reason why multiple victims would make false or mistaken charges, these arguments can be

indicated some possibility that they would commit rape if they could be assured they would not be punished; 21 percent indicated they would be likely to do so). But see Furby et al., supra note 42, at 27 (citing evidence suggesting that rapists have a higher rate of recidivism than pedophiles).

48 See Hutton, supra note 18, at 605, 623-25 (courts should not recognize a general child sex abuse exception, but a more limited use of abuser pattern - with expert testimony and appropriate opportunity for defendant to respond - would be appropriate).

49137 Cong. Rec. S3240 (daily ed. Mar. 13, 1991).

so $\quad I d$

$51 \quad$ Id. 
presented to the jury when such cases arise. ${ }^{52}$

The doctrine of chances analysis meets squarely the objection that the prior acts evidence is irrelevant or only weakly probative, but it does not meet the objection that the evidence will be prejudicial. As noted above, the traditional rule of exclusion is based in part on the fear that the jury will give evidence of prior crimes far greater weight than it deserves. Arguments can readily be made both for and against the proposed changes on this ground. In favor of the proposal it can be said that Rule $404(\mathrm{~b})$ reflects the overall judgment that the danger of prejudice from prior acts evidence is not sufficiently great to bar such evidence when it is relevant to prove some disputed issue. Once it has been determined that prior sex offenses are relevant to proving either the act or the intent elements in prosecutions for rape and child sex abuse, this evidence should be admitted subject to the court's general authority to exclude it in a particular case if its prejudicial impact outweighs its probative value. On the other hand, it can be argued that this general calculus should not apply when the prior acts are rape or child sex abuse, to which jurors typically react with anger and disgust. These strong negative reactions are likely to be the most prejudicial and difficult to counter.

Finally, it has been suggested that admitting in rape prosecutions the defendant's prior acts with others would be fundamentally inconsistent with the rape shield laws now in force in virtually every U.S. jurisdiction; such laws generally bar evidence of the victim's prior conduct with others. ${ }^{53}$ The commentary to the Bush administration proposal identifies three reasons for distinguishing between the prior acts of the accused and the complainant in rape prosecutions:

52 Id. In fact, it can be argued that in most cases the events would not be truly independent, and that an innocent person with a prior record of similar offenses is more likely than an innocent person without any prior record to be accused and to go to trial. See Richard O. Lempert \& Stephen A. Saltzburg, A Modern Approach to Evidence 217-18 ( $2 \mathrm{~d}$ ed. 1982) (an innocent person with a prior record is more likely to be apprehended because of bias in the investigative process, less likely to have weak charges dropped, and more likely to plea bargain since he or she knows that having a prior record makes conviction more likely).

See generally Harriett R. Galvin, Shielding Rape Victims in the State and Federal Courts, 70 Minn. L. Rev. 763 (1986). 
First, there is a basic difference in the probative value of the evidence that is subject to exclusion under such rules. In the ordinary case, enquiry by the defense into the past sexual behavior of the victim in a rape case will show at most that she has engaged in some sexual activity prior to or outside of marriage - a circumstance that does not distinguish her from most of the rest of the population, and that normally has little probative value on the question whether she consented to the sexual acts involved in the charged offense. In contrast, evidence showing that the defendant has committed rapes on other occasions places him in a small class of depraved criminals, and is likely to be highly probative in relation to the pending charge.

...

Second, the rape victim shield laws serve the important purpose of encouraging victims to report rapes and cooperate in prosecution by not requiring them to undergo public exposure of their personal sexual histories as a consequence of doing so. Rules limiting disclosure at trial of the defendant's commission of other rapes do not further any comparable public purpose . . .

Third, the victim shield laws serve the important purpose of safeguarding the privacy of rape victims. . . . In contrast, violent sex crimes are not private acts, and the defendant can claim no legitimate interest in suppressing evidence that he has engaged in such acts when it is relevant to the determination of a later criminal charge. ${ }^{54}$

\section{CONCLUSION}

The final question raised by the Bush administration proposal is whether its adoption would inevitably undermine the general rule limiting the introduction of prior acts. Of course, the proposal is limited on its face to prior acts of rape and child sex abuse, and the arguments based on 
greater likelihood of repetition are by their nature applicable only to a limited class of offenses. However, the doctrine of chances argument is applicable to any offense, and it has the potential to override the traditional rules strictly limiting the introduction of prior acts evidence. ${ }^{55}$

\section{APPENDIX: PROPOSED CHANGES TO THE FEDERAL RULES OF EVIDENCE ${ }^{56}$}

\section{Rule 413. Evidence of Similar Crimes in Sexual Assault Cases}

(a) In a criminal case in which the defendant is accused of an offense of sexual assault, evidence of the defendant's commission of another offense or offenses of sexual assault is admissible, and may be considered for its bearing on any matter to which it is relevant.

(b) In a case in which the government intends to offer evidence under this Rule, the attorney for the government shall disclose the evidence to the defendant, including statements of witnesses or a summary of the substance of any testimony that is expected to be offered, at least fifteen days before the scheduled date of trial or at such later time as the court may allow for good cause.

(c) This Rule shall not be construed to limit the admission or consideration of evidence under any other Rule.

(d) For purposes of this Rule and Rule 415, "offense of sexual assault" means a crime under Federal law or the law of a State that involved-

(1) any conduct proscribed by chapter $109 \mathrm{~A}$ of Title 18 , United States Code;

\footnotetext{
s5 Imwinkelried, supra note 24 , at 585-602.
}

56 See supra notes 1-2. 
(2) contact, without consent, between any part of the defendant's body or any object and the genitals or anus of another person;

(3) contact, without consent, between the genitals or anus of the defendant and any part of another person's body;

(4) deriving sexual pleasure or gratification from the infliction of death, bodily injury, or physical pain on another person; or

(5) an attempt or conspiracy to engage in conduct described in paragraphs (1)-(4).

\section{Rule 414. Evidence of Similar Crimes in Child Molestation Cases}

(a) In a criminal case in which the defendant is accused of an offense of child molestation, evidence of the defendant's commission of another offense or offenses of child molestation is admissible, and may be considered for its bearing on any matter to which it is relevant.

(b) In a case in which the government intends to offer evidence under this Rule, the attorney for the government shall disclose the evidence to the defendant, including statements of witnesses or a summary of the substance of any testimony that is expected to be offered, at least fifteen days before the scheduled date of trial or at such later time as the court may allow for good cause.

(c) This Rule shall not be construed to limit the admission or consideration of evidence under any other Rule.

(d) For purposes of this Rule and Rule 415, "child" means a person below the age of fourteen, and "offense of child molestation" means a crime under Federal law or the law of a State that involved-

(1) any conduct proscribed by chapter 109A of Title 18, United States Code, that was committed in relation to a child; 
(2) any conduct proscribed by chapter 110 of Title 18, United States Code;

(3) contact between any part of the defendant's body or any object and the genitals or anus of a child;

(4) contact between the genitals or anus of the defendant and any part of the body of a child;

(5) deriving sexual pleasure or gratification from the infliction of death, bodily injury, or physical pain on a child; or

(6) an attempt or conspiracy to engage in conduct described in paragraphs (1)-(5).

\section{Rule 415. Evidence of Similar Acts in Civil Cases Concerning Sexual Assault or Child Molestation}

(a) In a civil case in which a claim for damages or other relief is predicated on a party's alleged commission of conduct constituting an offense of sexual assault or child molestation, evidence of that party's commission of another offense or offenses of sexual assault or child molestation is admissible and may be considered as provided in Rule 413 and Rule 414 of these Rules.

(b) A party who intends to offer evidence under this Rule shall disclose the evidence to the party against whom it will be offered, including statements of witnesses or a summary of the substance of any testimony that is expected to be offered, at least fifteen days before the scheduled date of trial or at such later time as the court may allow for good cause.

(c) This Rule shall not be construed to limit the admission or consideration of evidence under any other Rule. 